\title{
Changes in the total electron content of the ionosphere during a geomagnetic storm August 31 - September 3, 2019 according to GPS data
}

\author{
Artem A. Kirilov \\ Vladimir N. Sychev*
}

\author{
Research Station of Russian Academy of Sciences in Bishkek City, \\ Bishkek, Kyrgyzstan \\ *E-mail: sychev@gdirc.ru
}

\begin{abstract}
RUS }}$
This article considers changes in the total electron content (TEC) in the ionosphere during a moderate geomagnetic storm $(\mathrm{Kp}=4-6)$ recorded in Kyrgyzstan between August 31 and September 3, 2019. This geomagnetic storm was recognized to be the longest-lasting among those registered in 2019. In order to obtain a quantitative assessment of changes arising in the ionospheric layer during such geomagnetic events, variations in the slope of the power spectrum of TEC fluctuations along the propagation path of the radio waves from GPS satellites to the receiving station were analysed. Using a sliding window method, the TEC time series was expanded in a Fourier series, and the slope of the power spectrum was calculated. As initial information, primary data provided by the GPS POL2 permanent station, which is a part of the IGS network, on the territory of Research Station of the Russian Academy of Sciences located in Bishkek were used. This station is equipped with a Javad Delta-3 receiver and a TPSCR.G3 highprecision antenna.
\end{abstract}

\section{Keywords}

magnetic storm, ionosphere, GPS, total electronic content, Fourier transform, power spectrum

For citation: For citation: Kirilov A.A., Sychev V.N. Changes in the total electron content of the ionosphere during a geomagnetic storm August 31 - September 3, 2019 according to GPS data. Geosistemy perehodnykh zon $=$ Geosystems of Transition Zones, 2020, vol. 4, no. 3, pp. 297-304. (In Russ.).

https://doi.org/10.30730/gtrz.2020.4.3.297-304

Для цитирования: Кирилов А.А., Сычев В.Н. Изменения полного электронного содержания ионосферы во время прохождения геомагнитной бури 31 августа - 3 сентября 2019 года по данным GPS.

Геосистемы переходных зон, 2020, т. 4, № 3, с. 297-304. https://doi.org/10.30730/gtrz.2020.4.3.297-304

\section{References}

1. Afraimovich E.L. 2006. GPS-monitoring verkhnei atmosfery Zemli [GPS-monitoring of the Earth's upper atmosphere]. Irkutsk: GU NTs RVKh VSNTs SO RAMN [SC of Reconstructive and Restorative Surgery of the ESSC of the SB RAMS], 480 p. (In Russ.).

2. Belakhovsky V.B., Pilipenko V.A., Sakharov Y.A. 2017. Geomagnetic and ionospheric response to the interplanetary shock on January 24, 2012. Earth Planets Space, 69(105). https://doi.org/10.1186/s40623-0170696-1

3. Candido C.M.N., Batista I.S., Klausner V. 2018. Response of the total electron content at Brazilian low latitudes to corotating interaction region and high-speed streams during solar minimum 2008. Earth Planets Space, 70(104). https://doi.org/10.1186/s40623-018-0875-8 
4. Cherniak I., Zakharenkova I. 2017. New advantages of the combined GPS and GLONASS observations for highlatitude ionospheric irregularities monitoring: case study of June 2015 geomagnetic storm. Earth Planets Space, 69(66). https://doi.org/10.1186/s40623-017-0652-0

5. Gokhberg M.B., Lapshin V.M., Steblov G.M., Shalimov S.L. 2011. Ionospheric response to Kuril undersea earthquakes from GPS satellite data. Issledovanie Zemli iz kosmosa = Earth Observation and Remote Sensing, 1: 30-38. (In Russ.).

6. Hofmann-Wellenhof B., Lichtenegger H., Collins J. 2001. Global positioning system: Theory and practice. Vienna, Springer-Verlag, 382 p. https://doi.org/10.1007/978-3-7091-6199-9

7. IGS: The International GNSS Service. URL: http://www.igs.org/igsnetwork/network_by_site.php?site=pol2 (accessed: 15.01.2020)

8. Ivanov V.A., Zhelonkin A.Yu., Ryabova N.V., Zuev A.V. 2011. Influence of geomagnetic disturbances on the ionospheric total electron content. Vestnik Mariiskogo gosudarstvennogo tekhnicheskogo universiteta. Ser. Radiotekhnicheskie i infokommunikatsionnye sistemy = Vestnik of Mari State Technical University. Series: Radio Engineering and Infocommunication Systems, 11(1): 24-30. (In Russ.).

9. Lanyi G.E., Roth T.A. 1988. Comparison of mapped and measured total ionospheric electron content using Global Positioning System and Beacon satellite observations. Radio Science, 23(4): 483-492. https://doi.org/10.1029/rs023i004p00483

10. Lou E., Wier S. 2014. Teqc Tutorial: Basics of Teqc Use and Teqc Products. UNAVCO Inc: 42. https://www.unavco.org/software/data-processing/teqc/doc/UNAVCO_Teqc_Tutorial.pdf

11. Mylnikova A.A., Yasyukevich Yu.V., Demyanov V.V. 2013. Estimation of absolute vertical total electron content in the ionosphere from GLONASS/GPS data. Solnechno-Zemnaya Fizika = Solar-Terrestrial Physics, 24: 70-77. (In Russ.).

12. Pezzopane M., Del Corpo A., Piersanti M. 2019. On some features characterizing the plasmaspheremagnetosphere-ionosphere system during the geomagnetic storm of 27 May 2017. Earth Planets Space, 71(77). https://doi.org/10.1186/s40623-019-1056-0

13. Ryazantseva M.O., Budaev V.P., Rakhmanova L.S., Borodkova N.L., Zastenker G.N., Yermolaev Y.I., Safrankova J., Nemecek Z., Prech L., Pitna A. 2017. Intermittency of the solar wind density near the interplanetary shock. Geomagnetism and Aeronomy, 57(6): 645-654. https://doi.org/10.1134/s001679321706010x 